\title{
Taalbeleidshersiening en die ontplanning van Afrikaans aan die Universiteit van die Vrystaat
}

\author{
Theodorus du Plessis \\ Eenheid vir Taalfasilitering en -bemagtiging, Universiteit van die Vrystaat, Suid-Afrika \\ E-pos: dplesslt@ufs.ac.za
}

\section{Opsomming}

Taalontplanning is ' $n$ onderwerp wat nie dikwels in die taalbeplanningsliteratuur voorkom nie. Van die enkele studies op die terrein ondersoek weliswaar die reëlmatige 'ontdoening' van vorige 'doenings'-aksies, maar dié studies konsentreer op taalkorpusbeplanning. Die skynbare verskraling van Afrikaans se posisie as hoëronderwystaal van Suid-Afrika laat die vraag ontstaan of ontdoeningsaksies met betrekking tot taalstatus- en taalfunksiebeplanning ook as taalontplanning beskou kan word. Omdat die onderhawige geval met ingrypende taalbeleidshersienings verbind kan word, ondersoek hierdie studie die verband tussen beleidshersiening - soms die agilleshiel van universiteite genoem - en taalontplanning. Die kollig val op die Universiteit van die Vrystaat (UV) se uitfasering van Afrikaans as hooftaal sedert 2015. Daar word in die aangebode studie gesteun op 'n analise van gedokumenteerde bewyse van taalbeleidshersiening aan die UV sedert die dringende noodsaak daaraan in 2008 deur twee nasionaal-gegenereerde eksterne verslae uitgewys is. Na aanleiding van voorskrifte omtrent beleidshersiening vervat in die UV se 2005-metabeleid en voorskrifte omtrent spesifiek taalbeleidswysigings vervat in die 2003- institusionele taalbeleid word uitstaande momente in taalbeleidshersiening aan hierdie instelling saaklik behandel. Die studie bevind dat beleidskontinuitteit 'n sleutelbegrip is om te kan onderskei tussen twee duidelike fases in taalbeleidshersiening aan die UV, 'n post-2008 tydperk waarin sodanige kontinuïteit nagestreef word, ofskoon relatief ingrypende wysigings desondanks deurgevoer word, teenoor die tydperk vanaf 2015 waarin taalbeleidskontinuïteit doelbewus verbreek word. Dit blyk dat die verskyning van 'n interne transformasieverslag teen die einde van 2014 'n sleutelrol gespeel het om hierdie koerswysiging te bewerkstellig en daarmee die weg help voorberei het vir die georkestreerde stigmatisering van parallelmediumonderrig (en deur assosiasie daarmee ook Afrikaans). So kon 'n intellektuele klimaat geskep word om met ontdoeningsaksies op gang te kon kom waardeur die ontplanning van Afrikaans aan die UV taalbeleidsmatig geïnstitusionaliseer kon word.

Trefwoorde: taalbeleid, taalbeleidshersiening, taalbeplanning, taalherplanning, taalontplanning 


\title{
Language policy review and the unplanning of Afrikaans at the University of the Free State
}

\begin{abstract}
Language unplanning is a topic that seldom features in language planning literature. Studies in the field that investigate the regular 'undoing' of previous language planning actions largely concentrate on language corpus planning. The apparent attenuation of the position of Afrikaans as higher education language of South Africa leads to questions whether the undoing of language status and function planning could also be considered as unplanning language. As the given case could be linked to radical language policy reviews, this study investigates the relation between policy review - sometimes called the Achilles heel of universities - and language unplanning. The spotlight falls on the phasing out of Afrikaans as main language at the University of the Free State (UFS) since 2015. Essentially this study relies on an analysis of documented evidence of language policy review at the UFS, since the urgency of this was pointed out in 2008 by two nationally generated external reports. Based on the UFS's 2005 meta-policy requirements concerning policy review and its 2003 language policy requirements on language policy review, significant moments related to language policy review at this institution are discussed briefly. The study finds that policy continuity is a key concept in differentiating between two distinctive phases in language policy review at the UFS, a post2008 period during which language policy continuity is pursued, although relatively radical changes are implemented notwithstanding, compared to the period from 2015, when language policy continuity was deliberately negated. It transpired that an internal transformation report released at the end of 2014 played a key role to effect this turn of the tide, paving the way for the orchestrated stigmatisation of parallel-medium teaching (and, by implication, also Afrikaans). Consequently, an intellectual climate could be cultivated that inspired undoing actions through which the unplanning of Afrikaans at the UFS could be institutionalised by means of a revised language policy.
\end{abstract}

Keywords: language planning, language policy, language policy review, language unplanning, language replanning

\section{Inleiding}

Die ontplanning van tale, ' $n$ onderwerp wat nie dikwels as sodanig in die gepaste literatuur ter sprake kom nie, het vanweë die meer onlangse sogenaamde verskraling van Afrikaans se posisie as (alternatiewe) hoëronderwystaal van Suid-Afrika relevant geraak. Waar outeurs soos Steyn (1980:15-18) al veel eerder gewys het op die nadelige uitwerking van sodanige statusvermindering op die behoud van Afrikaans as hoëfunksietaal, het die klem tot hiertoe nie pertinent op die moontlikheid van 'n planmatige 'ontverampteliking' van die taal geval nie. Die neiging onder outeurs sedert Steyn is om faktore wat "die toekoms van Afrikaans as openbare taal" raak en tot statusvermindering (kan) meewerk, te belig, soos Giliomee en Schlemmer (2001) in hulle bundel opstelle oor die verskraling van Afrikaans se ampstaalstatus gedoen het. Ook die hoëronderwyssituasie kom ter sprake, 'n tema wat sedertdien toenemend aandag geniet soos LitNet se "Universiteitseminaar/University Seminar" van getuig. Die aktualiteit van die tema het trouens die organiseerders van die "Derde Gentse colloquium over het Afrikaans" wat

1 Sien http://www.litnet.co.za/category/universitysa. 
gedurende Oktober 2016 aan die Universiteit van Gent aangebied is, genoop om een been van die byeenkoms te wy aan die taalsituasie in hoëronderwys in Suid-Afrika (Van Keymeulen 2017). By die aanhoor van die sowat 15 referate oor die tema sou 'n mens maklik die indruk kon kry van 'n sinistere, georkestreerde taalaksie jeens Afrikaans aan universiteite. Ten einde nie 'n slagoffer te word van so 'n samesweringsdiskoers nie, sou dit sin maak om die hele kwessie van taalbeleidshersiening aan voormalige Afrikaanse universiteite dalk eerder as 'n instrument van taalontplanning te probeer beskou. Dit sou die ondersoeker in staat kon stel om die verloop van taalbeleidshersiening aan sulke universiteite prosesmatig te bestudeer.

Wat die Universiteit van die Vrystaat(UV)-geval besonder interessant maak, is dat hierdie universiteit skynbaar in teenstelling met ander Afrikaanse universiteite nie enige ooglopende wysigings aan sy institusionele taalbeleid (UV 2003) aangebring het sedert dit in 2003 ingevolge 'n ministeriële opdrag aanvaar is nie. Volgens 'n vroeëre rektoreverslag het die voormalige Afrikaanse universiteite teen 2005 almal ingevolge hierdie opdrag 'n institusionele taalbeleid aanvaar (Rectors of the HAUs 2005). Drie van hierdie universiteite het sedertdien sonder enige eksterne ingryping hulle taalbeleide roetinematig hersien, die Universiteit van Pretoria in 2010 (UP 2010) en weer sedert 2015 (UP 2016), Noord-Wes Universiteit in 2012 (NWU 2014) en die Universiteit Stellenbosch in 2014 (SU 2014). Verdere, nie-roetinematige hersienings het gevolg: aan tweedegenoemde in 2014 en aan laasgenoemde in 2015 (SU 2016). Die betrokke hersienings behou grootliks Afrikaans as alternatiewe onderrigtaal, ofskoon miskien in 'n ietwat gewysigde hoedanigheid. Hierteenoor verwyder die UV se taalbeleid wat gedurende 2015 hersien is, Afrikaans as alternatiewe onderrigtaal en verklaar Engels as die primêre onderrigmedium (UFS 2016). Dit laat die vraag ontstaan of beleidshersiening in hierdie geval as instrument van ontplanning aangewend word.

Op grond van teoretiese opvattinge oor taalontplanning en beleidshersiening sal aangetoon word dat 'n mate van planmatigheid ter sprake kom by die wesenlike taalbeleidsoorname wat bedink is ten einde Afrikaans se status as voer- en werkstaal aan die UV te wysig.

\section{Taalbeplanning en taalontplanning}

Gebaseer op Kaplan en Baldauf (1997:3 e.v.) se benadering kan taalbeplanning heel eenvoudig omskryf word as 'n doelbewuste poging (ingryping) om die funksie (of status), korpus, verwerwing en prestige van 'n taal (of taalvariëteit) binne 'n spraakgemeenskap te beïnvloed. Só 'n definisie impliseer meestal 'n beleidgedrewe vorm van ingryping.

'n Mens behoort eerstens te onderskei tussen wat Kaplan en Baldauf (1997:297-299) as "onbeplande taalbeplanning” beskryf en dit wat elders as 'taalontplanning' beskryf kan word.

Onbeplande taalbeplanning hou verband met 'n taalverandering (in funksie of status, korpus, verwerwing, prestige) wat 'per ongeluk' voorkom, of wat voortspruit uit 'n laissez-fairebenadering tot taal. Dit impliseer dat onbeplande taalbeplanning meestal nie beleidgedrewe voorkom nie. Nietemin voorsien die outeurs dat gegewe bepaalde omstandighede die waarneembare taalverandering planmatig kan voorkom. Dit sou byvoorbeeld kon gebeur as 'n resultaat van krisisbestuur in 'n geval waar taalverandering dringend noodsaaklik is.

Taalontplanning daarenteen is meestal wel beleidgedrewe en word by uitstek daarop gerig om vorige taalbeplanning te 'ontdoen'. Ons sou selfs (heel lomp) kon praat van 'taalbeplanningsontdoening'. Sodanige beplande ontdoening kan aan die hand van 'n 
(alternatiewe) taalplan onderneem word. Een opvatting hieromtrent is dat ontdoening in werklikheid gepaard gaan met 'herdoening'. Só kom Clyne (1997:477) inderdaad tot die gevolgtrekking dat 'n onderskeiding tussen die betrokke twee begrippe wesenlik "onmoontlik" is en dat hulle in werklikheid albei vorme van "herplanning" verteenwoordig. Volgens hom gaan laasgenoemde meestal gepaard met politieke omwentelinge of veranderde prioriteite, binne kontekste dus waar samelewings spreekwoordelik besig is om "van rigting verander". Dit noem hy na aanleiding van Fishman, wat konstateer dat taalbeplanning net soos ander vorme van beplande sosiale verandering onderworpe is aan taalontplanning en taalherplanning (in Clyne 1997:500). Waar Clyne dit merendeels het oor korpusbeplanning, werp Fishman (2006:72-73) die net wyer. Volgens hom wys Clyne se werk uit dat die meeste taalbeplanning ter wêreld in werklikheid die beplanning en ontplanning van vorige beplanning behels; dat hierdie ontdoeningsaksies dus beslis nie beperk word tot korpusbeplanning nie. Dit spreek vanself dat sulke aksies ook aan universiteite kan voorkom waar dit veral gaan oor voertaalbeleid.

Omdat ons hier te make het met beleidgedrewe herplanning en ontplanning, kom die term 'beleidshersiening' onvermydelik ter sprake. 'n Verslag van die sogenaamde Institutional Policy Project waaraan verskeie Australiese, Nieu-Seelandse en Amerikaanse universiteite deelneem, suggereer dat beleidshersiening eintlik deel geword het van hoëronderwysinstellings se "beleidsiklus" (Freeman et al. 2014); met ander woorde 'n roetineaangeleentheid. 'n Tipiese beleidsiklus behels volgens EcoInformatics International Inc. (2006) 'n aantal identifiseerbare beplanningskomponente wat teoreties gesproke ook beleidsevaluering behels. Freeman (2012:3) moet egter toegee dat beleidsevaluering 'n aspek van die siklus is wat nog nie heeltemal posgevat het nie; die spreekwoordelike wit olifant aan universiteite. Nietemin bevind sy dat die metabeleide (dit is beleide oor beleide) van universiteite breedweg wel vir periodieke beleidshersiening voorsiening maak. Die probleem lê volgens haar eintlik by beleidsevaluering.

Tipiese faktore wat tot beleidsevaluering en by implikasie beleidshersiening aanleiding kan gee, sluit in interne ontwikkelinge, nuwe institusionele risiko's en die noodsaak om verskillende beleide met mekaar in ooreenstemming te bring. Ander weer, meestal die dwingender faktore, is ekstern van aard en spruit voort uit onder meer strukturele veranderinge (byvoorbeeld samesmeltings, amalgamerings), nasionale beleidswysigings, nuwe wetgewing en ander relevante nasionale tendense (Freeman 2012). Ook internasionale faktore, byvoorbeeld met betrekking tot dinge soos prestasie-yking en die gradering van instellings speel 'n rol. Sommige van hierdie faktore verg kleiner hersienings maar andere mag aanleiding gee tot ingrypender hersienings, wat selfs kan uitloop op beleidswysigings. 'n Mens sou laasgenoemde in verband kon bring met herplanning, gerig op beleidskontinuïteit. Waar sodanige kontinuïteit verbreek word, kry 'n mens waarskynlik met 'n vorm van revolusionêre beleidshersiening te make; in werklikheid dus beleidsvervanging. Hierdie tipe hersiening hou eerder verband met ontplanning. Dit is egter ook so dat nie alle taalbeleidshersiening noodwendig sigbare of overte beleidsveranderinge (moet) oplewer nie, soos onder meer Schiffman (1998), Spolsky (2004) en Shohamy (2006) ons leer.

Beleide verander kennelik na gelang van veranderende omstandighede. Die indruk wat Freeman (2012:3) en andere se werk skep, is dat dit vir universiteite toenemend belangrik raak om kritiese vrae oor beleidsrelevansie te stel en om hulle beleide so in te rig dat die evalueringskomponent roetinematigheid kan verseker. Dieselfde geld sekerlik ook vir universiteite se hantering van taalbeleid. Grin (2010:10) voel egter minder positief hieroor. Alhoewel hy 'n groot voorstander is van taalbestuur aan universiteite, meen hy dat 
universiteitsowerhede meestal die komplekse aard van taalbesluitneming totaal onderskat en gevolglik gewoonlik beleide daarstel sonder om die uiteindelike implikasies te begryp. Hy bepleit daarom 'n soberder benadering wat wegbeweeg van die populistiese en slagspreukagtige aansprake wat tipies in die jongste tyd toenemend oor Engels gemaak word.

Taalontplanning en taalherplanning kan dus begin by 'n evaluering van taalbeleid, hetsy na aanleiding van dwingende interne of eksterne faktore, wat dan kan uitloop op taalbeleidshersiening. Waar die hersiening uitloop op 'n beleidswysiging (met beleidskontinuïteit voor oë) kan daar sprake wees van wat Petrovic (2010:5) as "positiewe taalbeplanning" beskou, dit is taalbeplanning gerig op die vermeerdering van linguistiese opsies. Waar beleidskontinuïteit verbreek word en beleidsvervanging plaasvind, kom sekerlik die keersy ter sprake, naamlik wat Kaplan en Baldauf(1997:230) as "negatiewe taalbeplanning" beskryf. Negatiewe taalbeplanning hou verband met taalintervensies wat daarop gemik word om linguistiese opsies in te perk eerder as betekenisvol te vermeerder. Taalontplanning kan hiervolgens 'n nadelige uitwerking hê op mense se linguistiese opsies. Die betrokke outeurs noem pogings in Amerika om Engels as enigste ampstaal geproklameer te kry en sodoende skynbaar die sogenaamde verdelende uitwerking van taaldiversiteit hok te slaan as tipiese voorbeeld van 'n intervensie wat linguistiese opsies inperk. Daarenteen verteenwoordig Australiese beleid dat skoolkinders meer as een taal moet aanleer volgens hulle ' $n$ voorbeeld van 'n intervensie wat linguistiese opsies vermeerder.

Die vraag is nou of die UV met die taalbeleidshersiening wat gedurende 2015 aangepak en tot 'n nuwe taalbeleid gelei het as 'n geval van taalontplanning beskou kan word.

\section{Metodologie}

Omdat ons in die UV se geval pertinent met 'n beleidsingryping te make het, is daar vir die doeleindes van hierdie studie gepoog om gedokumenteerde bewyse hieromtrent te vind. Aangesien bestuursingryping by universiteitbeleid nie uit die lug val nie, behels dit die identifisering van bewyse wat korreleer met aanleidende faktore wat taalbeleidshersiening noodsaak; uiteraard bewyse van ingrepe wat spesifiek op die funksie, status en prestige van Afrikaans betrekking het.

Vernaamlik die veranderde taaldemografie aan die UV, ingevolge waarvan die Afrikaanse komponent reeds teen 2014 al minder as $30 \%$ van die studentekorps uitgemaak het, bring mee dat volwaardige parallelmediumonderrig op die duur gewoon nie volhoubaar is nie. Teoreties gesproke vereis hierdie onderrigmodel 'n regverdigbare taalverdeling om lewensvatbaar te kan bly. Al kom die kwessie van 'n veranderde taaldemografie wel in verskeie institusionele dokumente ter sprake is dit moeilik om gedokumenteerde bewyse te vind wat 'n direkte verband tussen hierdie faktor en die noodsaak aan taalbeleidshersiening toon.

Ook die andersoortige taalsentiment van 'n nuwe bestuur, ingevolge waarvan Engels toenemend as alleroplossing (met akademiese geletterdheid, sosiale gelykheid, politieke eenheid, ensovoorts) voorgehou word, speel mee. Liebenberg en Du Plessis (2013) voer aan dat die nuwe rektor (Jonathan Jansen) op daardie tydstip hierin 'n toonaangewende rol moes gespeel het deur sy karikaturisering van die tolke en die tolkdiens en sy openlike verheerliking van Engels as aangewese hoëronderwystaal in Suid-Afrika; ook sy kontroversiële uitlating tydens ' $n$ lesing van die English Academy of South Africa (SAPA 2013) gedurende Oktober 2013 dat Afrikaans transformasie in die onderwys teëhou. Só het hy wetend of onwetend help 
skep aan 'n ongunstige denkklimaat (sien Steyn 1980:49) aan die UV waarin 'n parallelmediummodel toenemend bevraagteken is en sodoende ook die rol van Afrikaans onder die soeklig gekom het. Bewyse is geïdentifiseer van besluite wat sedert die totstandkoming van 'n nuwe universiteitsbestuur na 2009 groter prominensie aan Engels verleen.

'n Veranderende beleidskonteks is 'n derde faktor. 'n Institusionele transformasieverslag (UFS 2014a) wat in Oktober 2014 bekendgestel is, identifiseer taaltransformasie aan die UV as strategiese prioriteit, en wend, weliswaar selektief, etlike bevindinge en aanbevelings van twee nasionale verslae oor die stand van parallelmediumonderrig ter motivering hiervoor aan - die sogenaamde HEQC- institusionele ouditverslag (HEQC 2008) en die Soudien-verslag ${ }^{2}$ oor transformasie aan universiteite (Ministerial Committee 2008).

Die HEQC-ouditverslag volg op 'n roetinematige institusionele oudit wat in 2006 aan die UV onderneem is en identifiseer ten minste 10 spesifieke probleme omtrent parallelmediumonderrig, onder meer dat die afsonderlike taalbane studente op 'n rassebasis verdeel, ongelyke assessering tot gevolg het, gelyke indiensneming belemmer en in elk geval op die lang duur nie volhoubaar is nie. Inligting vir hierdie verslag is hoofsaaklik op kwalitatiewe basis bekom en berus grootliks op die persepsies van respondente. Ofskoon die HEQC die instelling waarsku dat die beleid ernstige institusionele risiko's inhou, word 'n grootskaalse beleidswysiging nietemin nie vereis nie.

Die Soudien-verslag verskyn na aanleiding van 'n ondersoek deur 'n ministeriële komitee na transformasie en sosiale kohesie en die uitwissing van diskriminasie op Suid-Afrikaanse kampusse na aanleiding van die sogenaamde Reitz-insident van Februarie 2008 aan die UV. ${ }^{3}$ Ook hier word kwalitatief te werk gegaan, maar die ondersoek het veel minder respondente betrek. Vertolkings berus ook grootliks op persepsies. Die Soudien-verslag gaan verder en identifiseer parallelmediumonderrig as die enkele grootste struikelblok in die weg van transformasie omdat dit skynbaar rasseverdeling teweegbring (die gerapporteerde mening van enkele respondente). Nietemin maak hierdie verslag geen direkte aanbevelings oor die UVsituasie nie, maar konsentreer eerder op dinge wat die Minister van Hoëronderwys en Opleiding (hierna die Minister) moet doen. Hy word getaak om transformasie te moniteer deur middel van 'n meganisme vir taalbeleidsmoniterings. Dit doen hy deels deur middel van 'n oorsigkomitee oor transformasie (ondertussen opgerig), gereelde nasionale hoëronderwysberade (reeds twee) en 'n deurlopende gespreksforum met die hoëronderwysleierskap (DHET 2015).

Heelwat bewyse kon gevind word van etlike institusionele beleidsverstellings tussen 2008 en 2015 wat op een of ander wyse inspeel op die bevindinge en aanbevelings van hierdie twee verslae en wat dus die taalbeleidshersieningskonteks tot die 2015-hersiening verteenwoordig.

Die vermelde bewyse word aangetref in drie tipes post-2008- institusionele dokumente: beleidsdokumente; beplanningsdokumente en verslae; dokumentasie wat in die openbare

2 Vanweë die lang titel van die verslag het die gebruik ontstaan om dit te vernoem na die voorsitter van die betrokke ondersoekkommissie, prof Crain Soudien.

3 Die sogenaamde Reitz-insident hou verband met die onthulling van 'n video deur vier manlike Afrikanerstudente verbonde aan Pres Reitz Kamerwonings aan die UV, waarin uitgebeeld word hoe 'n groep ouerige swart werkers gedwing word om kos te eet waarin die mans oënskynlik geürineer het (Ministerial Committee 2008). 
ruimte beskikbaar is ${ }^{4}$ en wat iedereen dus vir navorsingsdoeleindes kan benut. Ongelukkig word die ondersoeker wel hierdeur ingeperk en benadeel dit kruiskontrolering. Nietemin bied die aard van die dokumentasie die moontlikheid om wel 'n mate van vergelyking te bewerkstellig. Die UV se institusionele jaarverslae (aan die Minister) kan vir kruiskontroledoeleindes aangewend word. 'n Mens kan aanvaar dat 'n institusionele jaarverslag sekerlik taalbeleidsingrepe gedurende die verslagjaar sal vermeld, ook al kom hulle in ander dokumente voor. Aangesien al die betrokke dokumentasie wel in die kuberruimte aangetref kan word, kon relevante (meestal Engelstalige) tekste geïdentifiseer word deur middel van 'n elektroniese soektog na relevante trefwoorde.

Die eerste rondte van dokument-analise het gekonsentreer op wat hierdie soektogte met betrekking tot die institusionele jaarverslae vir 2008 tot 2015 opgelewer het - vanaf 2014 heet hierdie jaarlikse verslae "Integrated Report" (vroeër "Annual Report"). Deur middel van kruisverwysings in die betrokke verslae kon natuurlik vasgestel word watter ander dokumentasie omtrent taalbeleid relevant is. Origens staan die UV se reeds vermelde transformasieverslag vir die tydperk 2004-2014 ook sentraal in die ondersoek.

Naas die institusionele jaarverslae dien die UV se strategiese planne as tweede belangrike bron vir die navolging van beleidsake. Altesaam vier strategiese planne kom in die ondersoek ter sprake vir onderskeidelik die tydperke 2006-2008 (in UFS 2008c), en 2009-2012 (in UFS 2009), opgeneem in die UV se 2008-jaarverslag en vir die tydperk 2012-2016 (UFS 2012a), die eerste sodanige plan onder 'n nuwe bestuur en 2015-2020 (UFS 2015a). Verbandhoudend hiermee is ook twee ander institusionele planne geïdentifiseer, naamlik die UV se institusionele verbeteringsplan (UFS 2008b) wat gedurende 2008 voortvloeiend uit die institusionele oudit by die HEQC ingedien is, en daaruit die UV se onderrig- en leerplan vir 2009-2012 (in UFS 2008c), ook volledig opgeneem in die 2008-jaarverslag.

In 'n derde rondte is gekonsentreer op beleidsdokumente self. Uiteraard staan die twee kerntaalbeleidsdokumente sentraal in die ondersoek, naamlik die 2003-taalbeleid en dié se plaasvervanger, die 2016-beleid. Ofskoon bewyse van die effektiewe hersiening van die 2003beleid gevind is, het dit nietemin onveranderd tot en met 11 Maart 2016 bly staan. Dit sluit in bewyse van die hersiening van beleidsbepalings in ander beleidsdokumente, onder meer in die beleid oor billike indiensneming, die onderrig- en leerbeleid (UFS 2008a), die koshuisplasingsbeleid en die handelsmerkidentiteitsbeleid (UV 2010). Enersyds suggereer dit dat nie alle taalbeleidshersienings sedert 2008 op konkrete taalbeleidswysiging of -verandering van die kerntaalbeleid uitgeloop het nie. Andersyds kan dit ook 'n refleksie wees van die vlak van taalbestuur aan die UV.

Mediabronne asook die bydraes van Van der Merwe (2015) en Luescher, Loader en Mugume (2016) kon aanvullend aangewend word om die verloop van taalbeleidshersiening tussen 2008 en 2015 te rekonstrueer. Ten einde 'n beeld te kan vorm oor die vlak van taalbestuur aan die instelling is dit egter nodig om stil te staan by die stand van taalbeleidshersiening aan die UV.

Ter wille van leesvlotheid en te wyte aan ruimtebeperking word verwysings na die relevante dokumente hierna nie onnodig herhaal nie.

4 UV-beleid omtrent die hantering van sensitiewe inligting (UFS 2013) beperk personeellede wat oor UV-sake skryf ongelukkig tot die verkenning van dokumentasie wat in die openbare domein beskikbaar is. 


\section{Beleid oor taalbeleidshersiening aan die UV}

In ooreenstemming met Freeman $(2012,2014)$ se punt hieromtrent moet kennis geneem word van die UV se metabeleid, veral met betrekking tot beleidshersiening maar ook van die 2003taalbeleid se baie pertinente bepalinge omtrent taalbeleidswysiging.

Die UV se metabeleid (UV 2005), weliswaar ietwat gedateer, bevat bepaalde stappe vir die ontwikkeling van nuwe institusionele beleid maar ook breë riglyne oor beleidshersiening. Kenmerkend van die beleid is 'n ooglopend konserwatiewe benadering wat onnodige beleidshersienings ontmoedig. Beleidmakers word aangeraai om alternatiewe maatreëls te ondersoek ten einde beleidsprobleme te probeer oplos. Beleidswysigings word as allerlaaste uitweg beskou.

'n Tekortkoming is dat die metabeleid op beleidsformaat konsentreer en vaag met die institusionele beleidsiklus omgaan. Die hele kwessie van beleidsevaluering kom rakelings ter sprake. Nietemin vereis die metabeleid dat elke institusionele beleid konkreet voorsiening maak vir beleidshersiening.

Afdeling 5 van die UV se 2003-taalbeleid oorkom van hierdie leemtes deur voorsiening te maak vir gereelde taalbehoeftebepalings met die oog op inligtingversameling om "ingeligte aanpassings" te kan maak. Advies hieromtrent word deur die "UV Taalkomitee" voorberei en aan vier belanghebbers voorgelê, naamlik die Kantoor vir Diversiteit en Billikheid, die Institusionele Forum, die Uitvoerende Bestuur, Senaat en Raad (Universiteitsraad). Die Taalkomitee word saamgestel uit lede van hierdie vier instansies. Voorsiening word ook gemaak vir die implementering van "enige maatreëls" ter verbetering van die effektiwiteit van die taalbeleid.

Hierbenewens maak Afdeling 8 van die 2003-taalbeleid eksplisiet voorsiening vir die hantering van "aanpassings". Aangesien meertaligheid “... 'n wesenlike en konstituerende element van die aard en grondslag" van die UV uitmaak, is enige wysiging aan die taalbeleid onderhewig aan goedkeuring deur 'n tweederdemeerderheid van die Uitvoerende Bestuur, Senaat en Raad. Dit sluit in enige wysiging met betrekking tot die oogmerke van die beleid, die wyse waarop meertaligheid binne die bestuur en administrasie gerealiseer word, asook veranderinge omtrent parallelmediumonderrig.

Ooreenkomstig die UV se metabeleid word derhalwe baie pertinent voorsiening gemaak vir taalbeleidsevaluering, ofskoon binne 'n konteks van taalverskansing. Wat agterweë bly, is 'n duidelike verbintenis tot periodieke hersiening as onderdeel van die institusionele beleidsiklus.

Die gemelde voorskrifte skep nietemin 'n beleidsraamwerk vir herplanningsaksies ten einde taalprobleme te hanteer en die taalbeleid effektief en relevant te hou; ontplanning word by implikasie ontmoedig. Alvorens nou gekyk word na hoe die hersiening van die taalbeleid gedurende 2015 verloop het, word saaklik stilgestaan by hersieningsaksies tussen 2008 en 2015 .

\section{Taalbeleidshersiening aan die UV, 2008-2015}

Bewyse omtrent taalbeleidshersiening aan die UV tussen 2008 en 2015 val uiteen in twee periodes: 'n relatief behoudende periode, gekoppel aan die UV se reaksie op (vernaamlik) die HEQC- en Soudien-verslae, teenoor 'n hervormende periode hierna tot en met 'n 
universiteitsvergadering van April 2015. Inisiatiewe gedurende die eerste periode, wat 'n formele hersiening van die kerntaalbeleid gedurende 2010 insluit, was minder ingrypend van aard. Gedurende die tweede periode, wat 'n tweede oorhoofse hersiening gedurende 2012 insluit, is die parallelmediumbeleid grondig hervorm.

Getuienis tussen Oktober 2008 en November 2010 omtrent die meer behoudende benadering tot taalbeleidshersiening word aangetref in die UV se sogenaamde Institutional Improvement Plan wat in Oktober 2008 aan die HEQC beskikbaar gestel is, asook in die UV se strategiese planne vir onderskeidelik 2006-2008 en 2008-2012, die transformasieplan vir 2007-2010 en die onderrig- en leerplan vir 2009-2012. Die verbeteringsplan reageer konstruktief op die bevindinge en aanbevelings van die twee eksterne 2008-verslae en stel 'n aantal maatreëls in werking wat spesifiek op implementeringsaspekte konsentreer. Dit sluit in die beter monitering van die taalbeleid, 'n studiehulpklasstelsel, modules om taalvaardighede te verbeter (van studente sowel as dosente), strenger assesseringsreëls, en 'n taalombudfunksie gekoppel aan die Taalkomitee. Hierdie maatreëls word uiteindelik geïntegreer by die gemelde beleide en planne. Volgens die UV se 2010-jaarverslag het die HEQC 'n vorderingsverslag omtrent die verbeteringsplan gedurende Junie 2010 positief ontvang (UFS 2010b:65). Verdere jaarverslae vermeld nie weer die plan nie.

Oor die 2010-hersiening van die kerntaalbeleid bestaan min inligting in die openbare domein. Skynbaar het die Senaat gedurende Oktober 2010 'n formele verslag hieromtrent hanteer (Du Plessis 2010:140). Meertaligheid word as taalbeleidsbeginsel behou en die posisie van Engels en Afrikaans as hooftale (nou weliswaar in omgekeerde taalrangorde) word onveranderd gelaat. Nietemin word ook besluit dat dringend ingegaan moet word op die 'negatiewe' aspekte van die taalbeleid en dat meer aandag geskenk sal word aan die taalvaardighede van studente en personeel. Jansen gee sy eie vertolking van hierdie besluite weer in sy DF Malherbegedenklesing deur "aan te kondig" (Steyn 2010:4) dat die UV tot 'n "tweetaalmodel" (let wel nie "parallelmedium" nie) verbind bly, maar dat die beleid in sy geheel "meer pragmaties" toegepas sal word (Jansen 2010:15).

Gedurende die tweede periode het hersienings geleidelik 'n meer 'hervormende' karakter begin aanneem; bestaande beleid is nog nie vervang nie. Getuienis hieromtrent kom voor in die taalbepalings van drie beleide (met betrekking tot handelsmerkidentiteit, koshuistoelating en billike indiensneming), in 'n tweede hersiening van die kerntaalbeleid gedurende 2012 en in verbandhoudende jaarverslae en strategiese planne.

Een betekenisvolle verandering in hierdie periode is die aanvaarding van 'n nuwe drietalige handelsmerkidentiteit teen die einde van 2010. Ingevolge hierdie beleidswysiging verplaas Engels nou Afrikaans (bo-aan) in die prominente handelsmerkposisie, ook wat betref die instelling se amptelike afkorting, "UFS/UV" (UV 2015d). Só word die subtiel omgekeerde taalrangorde wat gedurende die vorige periode ingesluip het nou geïnstitusionaliseer.

Gedurende 2011 word 'n addisionele koshuistoelatingsbeleid vir junior studente aanvaar (UFS 2011). Hierdie beleid bly grootliks verbind tot die uitstraling van diversiteit in koshuiswonings en die beginsel van meertaligheid, maar doen weg met 2007-taalreëlings (UFS 2007a), wat na afloop van die HEQC-oudit ingestel is. Só word die diversiteitsformule voortaan beperk tot 'n rasseverdeling (voorheen op basis van 'n gelyke taal- en rasseverdeling) en word weggedoen met die uitgebreide taalfasiliteringsmaatreëls. As gevolg hiervan word byvoorbeeld tolking in universiteitskoshuise vanaf 2013 gestaak (Du Plessis 2015:8). 
Die UV se 2012-jaarverslag vermeld 'n verdere taalbeleidshersieningsproses wat skynbaar gedurende die jaar van stapel gestuur is sonder om egter besonderhede te verskaf en wat die dalende getalletendense by huistaal-Afrikaanse studente beklemtoon (UFS 2012b). Nadere besonderhede word vervat in die UV se strategiese plan vir 2012-2016 (UFS 2012a). Weereens word die behoud van die parallelmediumbeleid bevestig en word selfs die voortgesette rol van Afrikaans op kampus benadruk. Desnieteenstaande word die 'taallas' wat die gewaande duplikasie van lesings meebring pertinent uitgelig. Dan volg drie beleidswysigings:

a) Engels en Afrikaans sal voortaan "waar prakties moontlik" binne die parallelmediummodel aangewend word. (Die 2003-taalbeleid stel die aanwending van Afrikaans en Engels as verstekopsie.)

b) Sotho sal as bykomende onderrigtaal ontwikkel word en kan reeds aangewend word in studiehulpklasse, werkstukke en buitekurrikulêre aangeleenthede. (Die 2003-taalbeleid voorsien inderdaad vir die "aanvullende gebruik" van Sotho, maar nie as "bykomende" onderrigtaal nie.)

c) Sekere eerste- en tweedejaarsklasse kan in al drie tale aangebied word. (Die 2003taalbeleid maak vir Afrikaans en Engels voorsiening.)

In 2013 kom 'n hersiening van die billike-indiensnemingsplan vir 2013-2016 (UV 2013) met 'n nogal kontroversiële 'nuwe' taalreëling vorendag: dit is wenslik dat Engels voortaan aangewend sal word binne situasies waar taal 'n struikelblok raak. Die vorige twee planne, vir 2007-2010 (UFS 2007b:33) en vir 2010-2013 (UFS 2010a), bevat nie so 'n bepaling nie. Eersgenoemde voorsien nog vir taalreëlings by frontlinie-steundienste en vir taalbemagtiging iets wat die jongste twee planne verswyg. Al drie weergawes beklemtoon nietemin die uitdagings omtrent die tweetaligheidsvereiste by indiensneming.

Ofskoon die HEQC die UV se institusionele verbeteringsverslag teen 2010 aanvaar het, het dit allermins beteken dat die aanvanklik geïdentifiseerde taalprobleme verdwyn het. Trouens, die feit dat beide die 2010- en 2012-taalbeleidshersienings die 'negatiewe aspekte' van die 2003taalbeleid as prominente uitdagings voorbehou, dui op 'n deurlopende diskoers; een wat ook in verskillende jaarverslae en strategiese planne manifesteer.

Buiten die korrektiewe maatreëls van die institusionele verbeteringsplan het opeenvolgende hersienings tot en met 2015 konstruktief op die voortslepende taaluitdagings ingespeel, hetsy op ' $n$ ad hoc-basis (byvoorbeeld na afloop van die 2008-ouditverslag en die hersiening in 2012) of as deel van 'n poging tot roetine-hersiening (byvoorbeeld in 2010 en 2015 en in die geval van die koshuistoelatingsbeleid en gelyke-indiensnemingsbeleid). So bring van die hersienings mee dat die werkslading van sommige dosente verminder is, dat Engels as voorkeurtaal begin funksioneer het, dat die "Afrikaanse" karakter van die UV begin verander het, dat Engelstaliges makliker aangestel kon word en dat meer ruimte geopen is vir die aanwending van Sotho as 'n derde taal van die UV; voorbeelde van positiewe herplanning.

In die lig van hierdie relatief konstruktiewe uitkomste is dit opvallend dat die UV se 2014transformasieverslag wat teen Oktober 2014 beskikbaar raak, die voorafgaande taalbeleidshersienings en hulle uitwerking heeltemal verswyg. In plaas daarvan verkies die samesteller(s) om enkele van die reeds in 2006 geïdentifiseerde knelpunte, dit is parallelmediumonderrig se verswaring van dosente se werkslas, die beweerde verskil in kwaliteit tussen Afrikaanse en Engelse lesse (skynbaar te wyte aan dosente se gebrekkige 
vermoë in Engels) en die feit dat die twee taalbane as't ware twee universiteite skep, opnuut aan die orde te stel. Desnieteenstaande hierdie probleme, ooreenkomstig die transformasieverslag 'n belemmernis vir die "deepening of transformation", verklaar die UV se strategiese plan vir 2015-2020 dat die UV nogtans 'n parallelmediuminstelling bly. Trouens, die primêre probleem omtrent parallelmediumonderrig wat hierdie plan uitlig, is die feit dat die veranderde demografiese profiel van die studentebevolking 'n bewese impak het op die verspreiding van studente wat onderrigmedium betref. Die probleem van dosente (en studente) se taalvaardigheid kom wel ook weer ter sprake as gevolg van 'n skynbaar betekenisvolle aantal Afrikaanse studente wat die Engelse onderrigbaan verkies. In teenstelling hiermee vermeld die UV se 2014- geïntegreerde jaarverslag (UFS 2014b) weer geen taalprobleme nie. Inteendeel, dié verslag lê klem op die sukses wat behaal word met taalontwikkeling in beide Engels en Afrikaans (aksies wat terugdateer na die 2008-verbeteringsplan) en die positiewe uitwerking wat dit op studentesukses het.

Aangesien die 2014-transformasieverslag by implikasie 'n taalbeleidsevaluering bevat, suggereer hierdie kontradiksies dat daar iets haper aan die wyse waarop die UV se taalbeleid tot en met 2015 bestuur is en dat die herplanningsinisiatiewe op uiteenlopende maniere getakseer word. Dit laat vrae ontstaan oor die basis waarop in 2015 besluit is om die 2003taalbeleid te hersien.

\section{Die 2015-taalbeleidshersiening}

Die UV se 2015-taalbeleidshersiening kom op gang nadat die Raad op 5 Junie 2015 die universiteitsbestuur hieromtrent mandateer (UV 2015c) en terselfdertyd die strategiese plan vir 2015-2020 (waarin die UV verbind bly tot die parallelmediumbeleid) aanvaar het. Sodanige "formele hersiening" moes volg op 'n omvattende konsultatiewe proses met alle belanghebbers. Die besluit behels "die totstandkoming van 'n Taalkomitee" om sodanige hersiening te behartig. Die samestelling van hierdie "taalkomitee" word nie openbaar gemaak nie, 'n besluit waaroor die media die UV herhaaldelik gehekel het (sien Smith 2015b). Volgens Van der Merwe (2015) het fakulteite en belanghebbers verteenwoordigers genomineer waarop die UV se Bestuurskomitee 'n ad hoc-komitee saamgestel het, die sogenaamde University Management Committee Language Committee (UFS 2015b). (Hierna word eerder na dié komitee as die Taalbeleidshersieningskomitee verwys.) Desondanks vereis die Ráád van hierdie komitee om te besin oor drie taalbeleidsmoontlikhede: die behoud van die parallelmediumbeleid; die aanbring van geringe aanpassings aan die beleid; en die aanbring van groot veranderings aan die bestaande beleid. Hersiening kon dus die behoud van die bestaande beleid of 'n wysiging daarvan behels (beleidskontinuïteit) maar uiteindelik selfs 'n vervanging inhou (beleidsdiskontinuïteit). Die UV se 2015-jaarverslag rapporteer 'n progressie tydens die hersieningsproses, aangedui met die woorde "revision" en "change" (tydens die verslagfase) en "new", met ander woorde vervanging (in die afhandelingsfase).

Wat het nou eintlik aanleiding gegee tot die 2015-taalbeleidshersiening? Sowel Jansen (in Smith 2015a) as Loader (2015) en Van der Merwe (2015) verbind die Junie-besluit aan 'n universiteitsvergadering van 28 April 2015 waartydens voorleggings oor die UV se taalbeleid gemaak is. Die oogmerk met hierdie byeenkoms was om vraagstukke met betrekking tot simbole, beleid, praktyke en die kurrikulum te behandel. Met bemiddeling van die Instituut vir Rekonsiliasie en Versoening (hierna die Instituut) is uiteindelik 12 aanbiedings gemaak waarvan vier oor taalbeleid gehandel het (UV 2015b). Vrae het skynbaar hier ontstaan oor “... die moontlike nie-geskiktheid van die UV se parallelle voertaalbeleid om diepgaande 
transformasie by die instelling te ondersteun" (Loader 2015 - eie beklemtoning). Jansen som die gemelde besware soos volg op: "parallelmediumonderrig segregeer, bevoordeel Afrikaanse studente en verswaar dosente se werkslas" (Smith 2015a - eie beklemtoning). Volgens Jansen het die Senaat op grond van hierdie voorleggings op 5 Mei 2015 by die Raad aanbeveel om hersiening te oorweeg. Hierteenoor sonder die UV se 2015-jaarverslag weer twee "marginaliseringskwessies" uit wat skynbaar die taalbeleidshersiening genoodsaak het: die aanbeveling (weliswaar word beklemtoon, nie verpligting nie) dat dosente in Afrikaans moet kan klasgee en die skynbaar "onvermydelike" uitsluiting van nie-Afrikaanssprekendes by formele departementele vergaderings. Verder noem die verslag dat studente al "'n dekade lank" parallelmediumonderrig kritiseer omdat dit skynbaar segregasie in klaskamers veroorsaak.

Daar bestaan onsekerheid oor wat nou juis tot die universiteitsvergadering van 28 April 2015 aanleiding gegee het. Die 2015-jaarverslag noem dat die noodsaak aan taalbeleidshersiening vir die eerste keer vroeër die jaar in 'n Senaatsvergadering deur die president van die Studenteraad geopper is. Volgens Luescher et al. (2016:5) kan die aanleiding weer aan 'n tweërlei faktore gekoppel word: die Instituut se April-veldtog "No-to-Racism/Yes-to-Equality" op UVkampusse en 'n beskeie \#SteynMustFall-studente-aksie, voortspruitend uit die \#RhodesMustFall-beweging (Bosch 2017:222), maar gemik op die verwydering van skynbaar kontensieuse Afrikanerstandbeelde op die hoofkampus. Die betrokke veldtog het 'n reeks kritiese gesprekke (tussen 8 en 10 April 2015) rondom die tema "Transformation of the university space" ingesluit (UV 2015a), wat gesien kan word as 'n institusionele respons op die landswye \#RhodesMustFall-beweging. Aan die Universiteit Stellenbosch het hierdie beweging in April aanleiding gegee tot die ontstaan van die sogenaamde \#OpenStellenbosch-beweging (OS 2015) wat grootliks vir die verwydering van Afrikaans as hooftaal aan hierdie universiteit agiteer. 'n Derde moontlikheid is dat 'n sameloop van al hierdie faktore, gekombineer met 'n katalitiese noodvergadering van die Minister met universiteitsleiers op 16 April 2015 tot die universiteitsvergadering aanleiding gegee het (Nel 2015). By hierdie ontmoeting is brandende vraagstukke na aanleiding van die \#RhodesMustFall-beweging behandel en het universiteite skynbaar hulle verbintenis tot verandering opnuut bevestig. Dit is opvallend dat die UV-bestuur plotseling op 20 April 2015, enkele dae na afloop van hierdie vergadering, die universiteitsvergadering aangekondig het (UFS 2015c).

Betrokke amptenare benadruk die omvattende konsultasieproses wat tussen Augustus en November 2015 onder leiding van die Taalbeleidshersieningskomitee onderneem is. Van der Merwe (2015) tipeer die proses as deursigtig, demokraties en inklusief en redeneer dit het voldoende geleentheid gebied vir deelname deur studente, personeel en ander belanghebbers. Volgens Luescher et al. (2016:6) is oor die tydperk altesaam 408 voorleggings ontvang, afgesien van bydraes deur geselekteerde kundiges. Van der Merwe (2015) meld dat, ofskoon nie deurslaggewend nie, die konsultasie tussen 29 Oktober en 4 November 2015 selfs 'n OVKbeheerde taalopname onder personeel en studente ingesluit het. Volgens uitgelekte inligting het 48,9\% van studente en personeel hierin ten gunste van die behoud van parallelmediumonderrig gestem en slegs 37,7\% vir 'n slegs Engelse model (Smith 2015b). Origens noem Van der Merwe (2015) dat die hele proses ook ondersteun is deur kwantitatiewe en dokumentêre inligting wat deur die UV se Directorate for Research and Academic Planning (Dirap) voorsien is en wat skynbaar ' $n$ oorsig van relevant nasionale beleid ingesluit het. Al hierdie inligting is uiteindelik vervat en verwerk in 'n verslag (nie as openbare dokument beskikbaar nie) wat voor die Bestuurskomitee, die Senaat, die Institusionele Forum en die Raad gedien het. 
Volgens Smith (2015b) word die Taalbeleidshersieningskomitee se verslag en aanbevelings op 20 November 2015 by 'n Senaatsvergadering behandel. Op grond daarvan maak die Raad op 4 Desember 2015 riglyne bekend vir die formulering van 'n "nuwe" (nie gewysigde nie) taalbeleid (UV 2015e). Die riglyne vir so 'n nuwe beleid, gebaseer op die kernwaardes van inklusiwiteit en meertaligheid, voorsien dat Afrikaans as hooftaal verdwyn en dat parallelmediumonderrig nie langer as verstekopsie bly bestaan nie; ook dat Afrikaans voortaan naas Sotho en Zoeloe binne 'n studiehulpklasstelsel aangewend sal word ten einde onderrig in Engels te vergemaklik.

Die finale beleid verskil nie wesenlik van hierdie riglyne nie. Etlike van die drastiese bepalings in die finale dokument word wel gekwalifiseer, soos dat Engels die "primêre" (in plaas van "enigste") onderrigtaal en taal van openbare tekens is, dat rekening gehou word met die einddoel om meertaligheid te bevorder en dat Afrikaans steeds verder as akademiese taal ontwikkel sal word; ook Sotho. Opdrag word gegee dat 'n implementeringsplan gedurende 2016 saamgestel word en dat die nuwe beleid op 1 Januarie 2017 in werking gestel word (UV 2016).

Met die aanvaarding van hierdie nuwe taalbeleid word die beleidskontinuïteit wat deur vorige hersienings bewerkstellig is, sigbaar opgehef. Só word die 2016-beleid die sentrale instrument by die ontplanning van Afrikaans aan die UV, 'n proses wat uiteraard oor die komende jare verder sal ontvou. Dit word egter duidelik dat die hele hersieningsproses vanuit die staanspoor sodanig 'geprogrammeer' is dat die uiteinde, gegewe die georkestreerde stigmatisering van parallelmediumonderrig (en deur assosiasie daarmee ook Afrikaans) sedert die verskyning van die 2014-transformasieverslag, eintlik voorspelbaar was. Daar is strategies te werk gegaan om die saak vir die ontplanning van Afrikaans voor te berei. Hiervoor was dit nodig om enkele van die destydse negatiewe bevindinge omtrent die parallelmediummodel opnuut te populariseer en deel te maak van die populistiese taalbeleidshersieningsdiskoers op kampus. Só is uiteindelik gehelp om 'n ongunstige denkklimaat oor die voortsetting van die parallelmediumbeleid te skep en oor Afrikaans se verdere rol op kampus. Die noodsaaklikheid aan getoetste inligting as basis vir besluitneming is sodoende effektief uitgeskakel. Daarom is dit glad nie verbasend dat die nuwe taalbeleid met 'n oorweldigende meerderheid aanvaar is nie.

\section{Slotsom}

Ofskoon 'n meer indringende vergelyking tussen die beplanningsaksies van die pre- en post2015-eras etlike leemtes in taalbestuur aan die UV kan blootlê, veral wat betref beleidsevaluering (en die versameling van substansiële inligting), beleidshersiening en die beleidsiklus, asook omtrent die prosedurele korrektheid en legitimiteit van die proses, was die fokus van hierdie bydrae op die manifestering van taalontplanning en taalherplanning. Die oorsigte van die verskillende taalbeleidshersieningsaksies wys die sentrale belang van 'n strewe na beleidskontinuïteit uit en die rol wat dit speel by taalontplanning en taalherplanning. Al het die taalherplanningsinisiatiewe tussen 2008 en 2015 bygedra tot die hervorming van die 2003taalbeleid, het dit - oorhoofs beoordeel - nie die linguistiese opsies van Afrikaanssprekende studente wesenlik verminder nie. Dit het wel die linguisties opsies van nie-Afrikaanssprekende studente (en dosente) vermeerder. Uit die gees van 2015 se hersieningsproses asook uit die 2016-teks van die nuwe taalbeleid word dit duidelik dat die inperking van Afrikaanssprekende studente (en dosente) se linguistiese opsies op hande was. Al kan dalk geredeneer word dat die aanwending van Afrikaans, Sotho en Zoeloe in die studiehulpklasse (indien dit wel gebeur) nie noodwendig linguistiese opsies inperk nie, kom die feit dat die voortsetting van parallelmedium 
(ironies genoeg ten spyte van al die besware daarteen) slegs in enkele rigtings en Engels as verpligte administrasietaal inderdaad neer op die inperking van toegestane linguistiese opsies; ten minste gesien vanuit die standpunt van 'n Afrikaanssprekende. Vanuit die standpunt van 'n Sotho- of Zoeloesprekende student impliseer die uitbreiding van meer inklusiewe parallelmediumonderrig sekerlik weer die vermeerdering van linguistiese opsies. Omdat die fokuspunt in hierdie studie op die status van Afrikaans aan die UV is, kom die doelbewuste, eintlik georkestreerde, breuk in taalbeleidskontinuïteit daarop neer dat elemente van taalontplanning wel voorkom. Of Afrikaanssprekendes se linguistiese opsies wesenlik ingekort word, bly voorlopig 'n betwisbare vraag.

\section{Bronnelys}

Bosch, S. 2017. Twitter activism and youth in South Africa: the case of \#RhodesMustFall. Information, Communication \& Society 20(2): 221-232.

Clyne, M. 1997. Epilogue. In M. Clyne (red.) Undoing and redoing corpus planning. Berlyn en New York: Mouton de Gruyter. pp. 477-500.

DHET (Department of Higher Education and Training). 2015. Annexure 1. Progress on resolutions of the 2010 Higher Education Summit. Report prepared for the second national Higher Education Transformation Summit 2015. Aanlyn beskikbaar:

http://www.dhet.gov.za/summit/Docs/2015Docs/Annex\%201_DHET_Progressre\%202010\%20HE\%2 0Summit\%20Resolutions.pdf (12 Mei 2016).

Du Plessis, T. 2010. Taalbeleid en onderrigtaalmodus aan die Universiteit van die Vrystaat. In F.W. de Klerk Stigting (red.) 'n Studie oor Afrikaans op Universiteitsvlak. Kaapstad: F.W. de Klerk Stigting. pp. 120-147.

Du Plessis, T. 2015. Is tolking op universiteitsvlak volhoubaar? Die geval Universiteit van die Vrystaat. Muratho 15(1): 6-12.

EcoInformatics International Inc. 2006. Policy mapping. Aanlyn beskikbaar: http://www.geostrategis.com/p_policy.htm (21 Junie 2016).

Fishman, J. 2006. Diglossia and societal multilingualism: Dimensions of similarity and difference. In N. H. Hornberger en M. Putz (reds.) Language loyalty, language planning, and language revitalization: Recent writings and reflections from Joshua A. Fishman. Clevedon, Buffalo en Toronto: Multilingual Matters. pp. 69-76.

Freeman, B. 2012. University policy review: What? Why? How? What's the big elephant? Referaat gelewer by die Association for Tertiary Education Management (ATEM) Policy Development Forum VIII, 26 Oktober 2012, Universiteit van Melbourne, Australië. Aanlyn beskikbaar: https://www.academia.edu/2060244/University_policy_review_What_Why_How_What_s_the_big_el ephant (14 Junie 2016). 
Freeman, B., N. Capell, A. Goldblatt, M. Lapan, T. Mafile'o en S. Thompson. 2014. An international comparative perspective on institutional policy to enhance institutional governance, policy-making and policy infrastructure, for improved institutional outcomes. Association of University Administrators (AUA) se jaarlikse kongres, Universiteit van Manchester, VK, 13-16 April 2014. Aanlyn beskikbaar: https://www.academia.edu/6917016/An_international_comparative_perspective_on_institutional_poli cy_to_enhance_institutional_governance_policy-

making_and_policy_infrastructure_for_improved_institutional_outcomes?auto=download (14 Junie 2016).

Giliomee, H. en L. Schlemmer (reds.). 2001. Kruispad: Die toekoms van Afrikaans as openbare taal. Kaapstad: Tafelberg.

Grin, F. 2010. Managing languages in academia: Pointers from education economics and language economics. Referaat gelewer by die Conference Professionalising Multilingualism in Higher Education, 4 Februarie 2010, Universiteit van Luxemburg, Luxemburg.

HEQC (Higher Education Quality Committee). 2008. Executive Summary. Audit Report of the University of the Free State. Report of the Higher Education Quality Committee to the University of the Free State, March 2008. Pretoria: Higher Education Quality Committee.

Jansen, J. 2010. Die politiek en vooruitsigte van Afrikaans, asook van Afrikaanse skole en universiteite. Die 29ste DF Malherbe-gedenklesing, 12 Augustus 2010, Universiteit van die Vrystaat, Bloemfontein, Suid-Afrika. Aanlyn beskikbaar: http://humanities.ufs.ac.za/dl/userfiles/Documents/00000/89_eng.pdf (22 Mei 2016).

Kaplan, R.B. en R.B. Baldauf, jr. 1997. Language planning from practice to theory. Clevedon: Multilingual Matters.

Liebenberg, L. en T. du Plessis. 2013. Interpreting at the bilingual University of the Free State. Sustainable? Referaat gelewer by die 2013 gesamentlike jaarkongres van die Suid-Afrikaanse Vereniging vir Taalonderrig (SAVTO), die Suider-Afrikaanse Vereniging vir Toegepaste Linguistiek (SAALA) en die Linguistevereniging van Suider-Afrika (LVSA), 1-4 Julie 2013, Stellenbosch, Universiteit Stellenbosch, Suid-Afrika.

Loader, L. 2015. UV se Taalbeleid word hiersien. Bult Nuustydskrif/News Magazine 2: 12-13. Aanlyn beskikbaar: http://apps.ufs.ac.za/media/dl/userfiles/documents/Publications/Bult/2015_Bult_2.pdf (13 Junie 2016).

Luescher, T., L. Loader en T. Mugume. 2016. \#FeesMustFall: An Internet-Age Student Movement in South Africa and the Case of the University of the Free State. Politikon 44(2): 1-14. doi: $10.1080 / 02589346.2016 .1238644$

Ministerial Committee. 2008. Report of the Ministerial Committee on Transformation and Social Cohesion and the Elimination of Discrimination in Public Higher Education Institutions. 30 November 2008. Final Report. Pretoria: Department of Education.

Nel, C-A. 2015. Nzimande, universiteite vergader. Volksblad, 17 April, p. 7.

NWU (North-West University). 2014. Institutional Language Policy of the North-West University. Date of approval 23 November 2012. Reviewed in 2014. Aanlyn beskikbaar: http://www.nwu.ac.za/sites/www.nwu.ac.za/files/files/i-governance-management/policy/2P-

2.5_Language_e.pdf (9 Junie 2016). 
OS (Open Stellenbosch). 2015. Open Stellenbosch@OpenStellies. Joined April 2015. Aanlyn beskikbaar: https://twitter.com/openstellies (13 Junie 2016).

Petrovic, J. 2010. Language minority education in the United States: Power and policy. In J. E. Petrovic (red.) International perspectives on bilingual education: Policy, practice, and controversy. Charlotte: Information Age Publishing. pp. 3-20.

Rectors of the HAUs. 2005. Promoting and enlarging the scope of multilingualism in higher education. Draft concept report prepared on behalf of the rectors of the UFS, UJ, NWU, UP and SU, 19 April 2005. Manuskrip.

SAPA. 2013. English-only comments distorted - Jansen. News24, 2 October. Aanlyn beskikbaar: http://www.news24.com/SouthAfrica/News/English-only-comments-distorted-Jansen-20131002

(1 Oktober 2014).

Schiffman, H. 1998. Linguistic culture and language policy. Londen: Routledge.

Shohamy, E. 2006. Language policy: Hidden agendas and new approaches. Londen en New York: Routledge.

Smith, C. 2015a. UV bekyk Afrikaans in klasse. Hersiening van taalbeleid aangeroer. Netwerk24, 7 Mei. Aanlyn beskikbaar: http://www.netwerk24.com/nuus/2015-05-07-uv-bekyk-afrikaans-in-klasse (25 Mei 2016).

Smith, C. 2015b. Engels, vra UV se taalskimme. Netwerk24, 19 November. Aanlyn beskikbaar: http://www.netwerk24.com/Nuus/Onderwys/engels-vra-uv-se-taalskimme-20151118?mobile=true (5 April 2016).

Spolsky, B. 2004. Language policy. Cambridge: Cambridge University Press.

Steyn, J. 1980. Tuiste in eie taal. Die behoud en bestaan van Afrikaans. Kaapstad: Tafelberg.

Steyn, J. 2010. Jansen: Nuwe taalbeleid aan die UV. Brief. Volksblad, 30 Augustus, p. 4.

SU (Stellenbosch University). 2014. Language Policy of Stellenbosch University. Revision approved by Stellenbosch University Council on 22 November 2014. Aanlyn beskikbaar: http://www.sun.ac.za/english/Documents/Language/Language\%20Policy\%202014\%20Final\%2012\%2 0Dec\%202014.pdf (13 Junie 2016).

SU. 2016. Language Policy of Stellenbosch University, 22 June 2016. Aanlyn beskikbaar: http://www.sun.ac.za/english/Documents/Language/Final\%20Language\%20Policy\%20June\%202016. pdf (9 Maart 2017).

UFS (University of the Free State). 2007a. Increasing diversity in UFS main campus residences: A new policy and role for residences. (Approved by the Council on 8 June 2007). Aanlyn beskikbaar: http://www.ufs.ac.za/docs/default-source/all-documents/increasing-diversity-in-ufs-main-campusresidences-101-eng.pdf?sfvrsn=0 (31 Mei 2016).

UFS. 2007b. Employment Equity Three-year Rolling Plan, October 2007-Sept 2010. Approved by the Council on 23 November 07. Aanlyn beskikbaar: http://www.ufs.ac.za/docs/defaultsource/employment-equity-documents/employment-equity-three-year-rolling-plan-oct-2007-sept2010-641-eng.pdf?sfvrsn=0 (18 Mei 2016). 
UFS. 2008a. Teaching-learning policy, 19 February 2008. Aanlyn beskikbaar: http://www.ufs.ac.za/docs/default-source/all-documents/teaching-learning-policy-120eng.pdf?sfvrsn=0 (7 April 2016).

UFS. 2008b. University of the Free State institutional improvement plan, October 2008. Aanlyn beskikbaar: http://www.ufs.ac.za/docs/default-source/policy-documents-documents/institutionalimprovement-plan-oct-2008-849-eng.pdf?sfvrsn=0 (7 April 2016).

UFS. 2008c. Annual Report to the Minister of Education 2008. Aanlyn beskikbaar: http://www.ufs.ac.za/docs/default-source/annual-report-to-the-minister-of-educatoin/2008-annualreport-94-eng.pdf?sfvrsn=0 (7 April 2016).

UFS. 2009. Annual Report to the Minister of Higher Education and Training 2009. Aanlyn beskikbaar: http://www.ufs.ac.za/docs/default-source/almal-dokumente/2009-annual-report-93-afr.pdf?sfvrsn=0 (7 April 2016).

UFS. 2010a. Employment Equity Three-year Rolling Plan, 1 October 2010 - 30 September 2013. Approved by the University Management Committee on 29 October 2010. Aanlyn beskikbaar: https://www.ufs.ac.za/docs/default-source/employment-equity-documents/employment-equity-threeyear-rolling-plan---oct2010---sep2013-640-eng.pdf?sfvrsn=0 (23 Mei 2017).

UFS. 2010b. Annual Report to the Minister of Higher Education and Training 2010. Aanlyn beskikbaar: http://www.ufs.ac.za/docs/default-source/belesidsdokumente-dokumente/jaarverslag-846afr.pdf?sfvrsn=0 (7 April 2016).

UFS. 2011. Policy and additional regulations concerning the placement of students in junior residences, Main Campus, 2011-07-19. Aanlyn beskikbaar:

http://www.ufs.ac.za/docs/librariesprovider32/housing-and-residence-affairs-documents/servicesdocuments/placement-policy-junior-residences-103-eng.pdf?sfvrsn=0 (28 Julie 2016).

UFS. 2012a. University of the Free State Strategic Plan 2012-2016. Aanlyn beskikbaar: http://www.ufs.ac.za/docs/default-source/all-documents/strategic-plan-931.pdf?sfvrsn=4 (25 Mei 2016).

UFS. 2012b. Annual Report to the Minister of Higher Education \& Training. Aanlyn beskikbaar: https://www.ufs.ac.za/docs/default-source/annual-report-to-the-minister-of-educatoin/annual-reportto-the-minister-2012-2536.pdf?sfvrsn=6 (7 April 2016).

UFS. 2013. Information Security Policy for Users of Information. As amended on 2 October 2012 and approved on 18 February 2013. Aanlyn beskikbaar: http://www.ufs.ac.za/docs/default-

source/policy-documents-documents/information-security-policy-for-users-of-information-854eng.pdf?sfvrsn=0 (5 Mei 2016).

UFS. 2014a. Transformation report 2004-2014. Aanlyn beskikbaar:

http://www.ufs.ac.za/docs/librariesprovider39/reports-documents/transformation-report-74eng.pdf?sfvrsn=0 (5 April 2016).

UFS. 2014b. 2014 Integrated report University of the Free State. Aanlyn beskikbaar: http://www.ufs.ac.za/docs/default-source/all-documents/2013-integrated-report-2309eng.pdf?sfvrsn=0 (5 April 2016).

UFS. 2015a. University of the Free State Strategic Plan 2015-2020. Aanlyn beskikbaar: http://www.ufs.ac.za/docs/default-source/all-documents/ufs-strategic-plan-2015---2020.pdf?sfvrsn=0 (30 Maart 2016). 
UFS. 2015b. University of the Free State Annual Report to the Minister of Higher Education and Training 2015. Aanlyn beskikbaar: http://www.ufs.ac.za/docs/default-source/alldocuments/2015.pdf?sfvrsn=0 (26 Januarie 2016).

UFS. 2015c. University Assembly: Invitation to all staff and students, 20 Apr 2015. Aanlyn beskikbaar: http://www.ufs.ac.za/templates/news-archive-item?news=6313 (25 Mei 2016).

UFS. 2016. University of the Free State Language Policy. Approved by the UFS Council on 11 March 2016. Aanlyn beskikbaar: https://www.ufs.ac.za/docs/default-source/policy-institutionaldocuments/language-policy.pdf?sfvrsn=0 (10 Mei 2017).

UP (University of Pretoria). 2010. Language policy. Document number: $R$ 16/10. Approved by Council on 20 August 2010. Aanlyn beskikbaar:

http://www.up.ac.za/media/shared/Legacy/sitefiles/file/1/elzanie/r1610languagepolicy.pdf (15 Junie 2016).

UP. 2016. Announcement: Revision of the University of Pretoria's Language Policy, 1 February 2016. Aanlyn beskikbaar: http://www.up.ac.za/en/news/post_2222129-announcement-revision-of-theuniversity-of-pretorias-language-policy (13 Junie 2016).

UV (Universiteit van die Vrystaat). 2003. Taalbeleid van die Universiteit van die Vrystaat. Deur die $U V$-raad goedgekeur op 6 Junie 2003. Aanlyn beskikbaar: http://www.ufs.ac.za/docs/defaultsource/almal-dokumente/taal---beleid-335-afr.pdf?sfvrsn=0 (4 April 2016).

UV. 2005. Riglyne vir beleidsformulering, -ontwikkeling en -hersiening: Universiteit van die Vrystaat, 10 Junie 2005. Aanlyn beskikbaar: http://www.ufs.ac.za/docs/default-source/almal-dokumente/riglynevir-beleidsformulering--ontwikkeling-en-hersiening-157-afr.pdf?sfvrsn=0 (5 April 2016).

UV. 2010. UV wil leiding neem. Promosie Universiteit van die Vrystaat. Volksblad, 3 Desember, p. 7.

UV. 2013. Plan vir Billike Indiensneming, 1 Oktober 2013 - 30 September 2016. 1 Oktober 2013 - 30 September 2016. Aanlyn beskikbaar: http://www.ufs.ac.za/docs/default-source/billike-indiensnemingdokumente/2014-02-03---employment-equity-three-year-plan-(oct-2013---sept-2016)-2471afr.pdf?sfvrsn=0 (1 Junie 2016).

UV. 2015a. Diskoers oor standbeelde en simbole plaas transformasiekwessies onder die soeklig 12 Apr 2015. Aanlyn beskikbaar: http://www.ufs.ac.za/af/template/nuusargief-item?news=6337 (25 Mei 2016).

UV. 2015b. Universiteitsvergadering fokus op simbole, beleid, praktyke en kurrikulums 30 Apr 2015. Aanlyn beskikbaar: http://www.ufs.ac.za/af/template/nuusargief-item?news=6337 (25 Mei 2016).

UV. 2015c. Sake deur die UV-Raad goedgekeur tydens 'n vergadering op Vrydag 5 Junie 2015, 11 Jun 2015. Aanlyn beskikbaar: http://www.ufs.ac.za/af/template/nuusargief-item?news=6368 (5 April 2016).

UV. 2015d. Handelsmerk-identiteitsriglyne, September 2015, Departement Kommunikasie en Handelsmerkbestuur. Aanlyn beskikbaar: http://www.ufs.ac.za/af/media/riglyne/handelsmerkriglyne (22 Mei 2016).

UV. 2015e. UV-Raad keur riglyne vir die ontwikkeling van 'n nuwe Taalbeleid goed, 4 Des 2015. Aanlyn beskikbaar: http://www.ufs.ac.za/af/template/nuusargief-item?news=6582 (7 April 2016). 
UV. 2016. UV-Raad keur 'n nuwe Taalbeleid goed. Aanlyn beskikbaar: http://www.ufs.ac.za/af/template/nuusargief-item?news=6694 (14 April 2016).

Van der Merwe, J. 2015. Leaked language report: UFS sets the record straight. Council to decide next week. The Journalist, 60. Aanlyn beskikbaar: http://www.thejournalist.org.za/spotlight/leakedlanguage-report-ufs-sets-the-record-straight (2 Junie 2016).

Van Keymeulen, J. 2017. Beleid gekap, nié taal. Beeld, 3 Januarie. Aanlyn beskikbaar: https://www.pressreader.com/south-africa/beeld/20170103/282076276541283 (20 April 2017). 